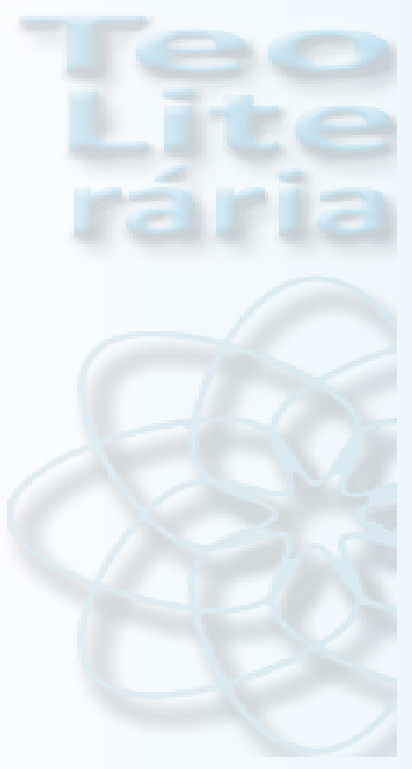

Artigo recebido em

$30 / 04 / 2016$

e aprovado em

02/12/2016.

V. $6-$ N. $12-2016$

* Doutora em Letras pela UFF, Professora na Universidade do Estado de Minas Geraise na Faculdade de Ciências Gerenciais de Manhuaçu. Email: lidianazare@hotmail.com.

** Graduando do curso de Letras da Universidade do Estado de Minas Gerais (Unidade de Carangola).

Email: leonardogomes. jhs@gmail.com.

\section{O sentido do "segue-me" de Jesus Cristo}

\section{Jesus Christ's Follow-me sense}

\section{Lídia Maria Nazaré Alves}

\section{Leonardo Gomes de Souza}

\section{Resumo}

Esse trabalho foi desenvolvido em torno das narrativas e linguagens sacro-religiosas. À luz dessas, e também de pensadores pós-modernos, questionou-se sobre a possibilidade ou não do "segue-me" de Jesus Cristo ser experimentado atualmente como o fora pelos primeiros cristãos. Levantou-se uma hipótese positiva, que foi comprovada, a partir do pressuposto de que tal experimentação é possível, desde que se escute e se obedeça a Palavra de Deus e se faça a travessia de uma catequese tradicionalista antropológica a uma catequese pós-moderna querigmática.

Palavras-chaves: Palavra de Deus, Seguimento, Individualismo, Comunidade, catequese.

\section{Abstract}

This paper was developed around the narratives and sacral religious languages. In the light of these, and also of post-modern thinkers, the question is about whether or not the "follow me" of Jesus Christ is now 
experienced how it was by the early Christians. It rose a positive hypothesis, which was proven from the assumption that such experimentation is possible since the Word of God is listened and obeyed and make the crossing of an anthropological traditionalist catechesis to a postmodern kerygmatic catechesis.

Keywords: Word of God, Follow, Individualism, Community Catechesis.

\section{Introdução}

ste artigo está desenvolvido em torno do tema "Narrativas Sagradas e linguagens religiosas". No assunto a ser desenvolvido, intenta-se adentrar a narrativa religiosa, a fim de capturar-Ihe sentidos que ainda não foram bem explorados, embora alguns possam objetar, haja vista a quantidade de trabalhos a respeito. Entende-se que o texto bíblico seja uma obra aberta, literária, portanto, que se disponibiliza a diferentes possibilidades de leituras aos que desejam debruçar-se sobre ela.

A fim de encaminhar com maior propriedade o assunto, elaborou-se o seguinte problema: É possível encontrar pontos convergentes entre o modo de experimentar o "segue-me" de Jesus Cristo, dos primeiros discípulos, aos seguidores atuais e qual a relação deste "segue-me" com a fase atual da modernidade?

Para encaminhar uma discussão mais produtiva, elaboraram-se duas hipóteses, a saber: $1^{a}$. É possível encontrar pontos convergentes na proposta da Palavra de Deus concretizada na vida do cristão; $2^{\circ}$ Os desafios à vivência da proposta da Palavra, hoje, concentram-se na fluidez do comunitário e no individualismo moderno.

Este artigo justifica-se em virtude do sentimento de perdição a que está submetido o homem e, no nosso caso, o homem cristão 
pós-moderno. Nesses termos, objetiva-se com o mesmo viabilizar uma reflexão sobre a maneira como o chamado de Jesus Cristo foi atendido, em diferentes tempos, e ainda se se podem encontrar pontos convergentes no atendimento ao referido.

A metodologia pela qual se optou é pesquisa de cunho bibliográfico com análise de um texto bíblico comumente chamado "O jovem rico". A fim de assegurar a credibilidade do artigo elegeram-se, para sustentar as argumentações, os estudos do biblista Ivo Storniolo (2011), do teólogo e literato João Cesário Leonel Ferreira (2008), do teórico Terry Eagleton (2006), da catequeta Solange Maria Do Carmo (2012), do sociólogo Zygmunt Bauman (2001) e dos documentos magisteriais da Igreja Católica, mais diretamente ligados ao Concílio Ecumênico Vaticano II.

\section{Evangelho de Mateus: Um olhar teo-literário.}

Intenta-se estudar neste tópico as duas dimensões do texto bíblico: a teológica e a literária. A dimensão teológica será feita a partir do biblista Ivo Storniolo (2011). Para o biblista o evangelho de Mateus e a atuação de Jesus neste só pode ser analisada sob a ótica da justiça social.

A ação de Cristo busca dar vida e liberdade às pessoas. Jesus é o libertador que com seu exemplo e coragem enfrenta um sistema corrupto que tem por base a exploração de inocentes. Jesus também denuncia a falsa religião, como uma capa externa. Esta impermeabiliza o crente e fecha seus olhos ao outro.

Na ótica de Storniolo a ação cristã tem por base a ação de Jesus. Para ele seguir Jesus é lutar para que todos tenham vida e liberdade. Isto, porém, tem consequência. Assim como Jesus foi 
morto o cristão que se dispõe a lutar pelo próximo também arcará com as consequências. Porém Storniolo deixa claro que a vida para o cristão não está aqui. Nós passamos por aqui para alcançarmos o bem maior: O Paraíso. (Cf. STORNIOLO, 2011).

A dimensão literária está aqui entendida a partir dos estudos feitos por Terry Eagleton (2006). Segundo o teórico muitas são as tentativas de definir literatura. Há quem a defina como a escrita advinda da imaginação "no sentido de ficção". Sobre isto fala Eagleton "mas se refletirmos, ainda que brevemente, sobre aquilo que comumente se considera literatura, veremos que tal definição não procede." (2006, p.1).

A diferenciação de real e ficcional na literatura não é útil, pois é subjetiva e sujeita a alteração ao longo do tempo. No texto literário há a presença de ambas as categorias até porque "se a 'literatura' inclui muito da escrita 'fatual', também exclui uma boa parte da ficção". (EAGLETON, 2006, p.2) Por outro lado "O fato de a literatura ser a escrita 'criativa' implicaria serem a história, a filosofia e as ciências naturais não-criativas e destituídas de imaginação?" (EAGLETON, 2006, p.2)

Para o autor é necessária uma nova abordagem e propõe que a literatura seja definida não como "imaginativa", mas sim "porque emprega a linguagem de forma peculiar". (EAGLETON, 2006, p.3) Para esta teoria "literatura representa uma 'violência organizada contra a fala comum'" (EAGLETON, 2006, p.3), isto é, "a literatura transforma e intensifica a linguagem comum, afastando-se sistematicamente da fala cotidiana." (EAGLETON, 2006, p.3).

A linguagem literária, para esta teoria, é auto- referencial, pois "Trata-se de um tipo de linguagem que chama a atenção sobre 
si mesma e exige sua existência material" (EAGLETON, 2006, p. $3)$. Esta teoria surgiu com os formalistas russos. Eles "surgiram na Rússia antes da revolução bolchevista de 1917; suas ideias floresceram durante a década de 1920, até serem eficientemente silenciados pelo stalinismo" (EAGLETON, 2006, p.3)

Os formalistas romperam com as ideias simbolistas e "imbuídos de um espírito prático e científico, transferiram a atenção para a realidade material do texto literário em si". Para eles literatura era senão "uma organização particular da linguagem". Esta "organização" "era um fato material, cujo funcionamento podia ser analisado mais ou menos como se examina uma máquina." (EAGLETON, 2006, p.4)

Em suma "o formalismo foi a aplicação da linguística ao estudo da literatura". A linguística desta fase "era do tipo formal". Tinha seus olhos voltados para a estrutura/forma e desinteressava-se pela fala, pelo dizer. Assim "os formalistas passaram ao largo da análise do 'conteúdo'”. Nesta relação forma-conteúdo eles acreditavam que "o conteúdo era simplesmente a 'motivação' da forma, uma ocasião ou pretexto para um tipo específico de exercício formal". (EAGLETON, 2006, p.4)

Na relação arte e social não havia um antagonismo entre as partes, mas "os formalistas afirmavam, provocadoramente, que essa relação fugia ao âmbito do trabalho crítico.". (EAGLETON, 2006, p.5)

No início, os formalistas tinham no texto literário um conjunto de 'artifícios'. Só depois enxergaram a relação entre os mesmos. Artifícios aqui se referem a "todo o estoque de elementos literários formais; e o que todos esses elementos tinham em co- 
mum era o seu efeito de 'estranhamento' ou 'desfamiliarização'.”. (EAGLETON, 2006, p.5)

O específico da linguagem literária "era o fato de ela 'deformar' a linguagem comum de várias maneiras.". Isto porque "sob a pressão dos artifícios literários, a linguagem comum era intensificada, condensada, torcida, reduzida, ampliada, invertida". Em consequência disto à linguagem comum "se 'tornara estranha', e, graças a este estranhamento, todo o mundo cotidiano transformava-se, subitamente, em algo não familiar". (EAGLETON, 2006, p.5) Sobre isto fala os formalistas "a literatura, impondo-nos uma consciência dramática da linguagem, renova essas reações habituais, tornando os objetos mais "perceptíveis'”.

Em resumo "os formalistas, portanto, consideravam a linguagem literária como um conjunto de desvios da norma, uma espécie de violência linguística: a literatura é uma forma 'especial' de linguagem 'comum', que usamos habitualmente." (EAGLETON, 2006, p.6).

Nossa atenção se voltará, em especial, para a narrativa do Jovem rico, do evangelho segundo São Mateus. Desta forma, objetiva-se, com esta escrita, promover uma análise mais profunda sobre a narrativa bíblica aludida.

O texto da já citada conta um diálogo entre Jesus e um jovem rico. O questionamento do Jovem a Jesus era o que ele deveria fazer para ganhar a vida eterna. Jesus lhe responde citando o decálogo. Em resposta a isto o jovem afirma cumprir esses mandamentos, desde a infância, o que gera o convite de Jesus: "Se você quer ser perfeito, vá, venda tudo o que tem, dê o dinheiro aos pobres, e você terá um tesouro no céu. Depois venha e siga-me". 
(Mt 19, 16 - 22)

João Cesário Leonel Ferreira em artigo intitulado "A bíblia como literatura - lendo as narrativas bíblicas" afirma que "a fim de persuadir o leitor, ao compor sua narrativa, o escritor utiliza a combinação dos elementos: narrador, tempo, cenário, personagens enredo" (2008, p.11). Na esteira de tal afirmação entendemos que para termos uma visão mais clara de um texto temos de considerar e analisar cada um desses elementos. Neste trabalho, porém, nos ateremos ao narrador.

Segundo Ferreira "toda história provém de uma voz que a conta. As narrativas são construídas a partir das articulações desenvolvidas pelo narrador. É ele quem determina como a história chega a nós, leitores" (2008, p.11). Essa fala permite que se perceba a centralidade do narrador no processo de construção das narrativas. Ferreira reconhece no texto literário dois planos, o que, aliás, já é lugar comum entre os teóricos da literatura. O primeiro é o explícito e o segundo implícito. Na medida em que o texto é claro, objetivo, pormenorizado o primeiro plano reina sobre o segundo. Ao contrário, quanto maior é a lacuna descritiva com mais intensidade o segundo nível, o nível implícito aparece. Em uma interpretação histórica valoriza-se o nível explícito em detrimento do segundo nível que é considerado uma "debilidade textual" (FERREIRA, 2008, p.12). Em uma interpretação de cunho literário esta situação se inverte: "A presença do segundo plano é sinal de uma obra literária densa, enquanto que o primeiro plano demonstra sinais de superficialidade" (FERREIRA, 2008, p.12). É o segundo plano que faz do texto bíblico um espaço de comunicação entre o divino e o humano. Também é este espaço que faz do texto bíblico uma chave para a interpretação da realidade. 
Se analisarmos o texto que estamos usando como corpus, ou seja, o texto do jovem rico, um exemplo deste segundo plano e como este viabiliza a comunicação, está no versículo 16. "Um jovem se aproximou e disse a Jesus 'Mestre, que devo fazer de bom para possuir a vida eterna?'”. O narrador indefine a figura que se coloca a dialogar com Jesus. No texto ele é caracterizado parcamente, por sua condição financeira e, certamente, o narrador o faz propositalmente. Ferreira traz outro exemplo que ajuda no entendimento do que se está dizendo a respeito do Jovem rico. $\mathrm{O}$ professor, em seu artigo, trabalha com o texto do livro do gênese (Gn 22, 1-18) onde Deus pede que Abraão que sacrifique seu fiIho primogênito, Isaque. O texto guarda em segredo os acontecimentos da caminhada de Abraão até o local do sacrifício. "Nesse caso, o narrador se nega a dar maiores explicações, permitindo que o leitor, que pode ser um pai ou uma mãe, se coloque no lugar de Abraão e reconstrua mentalmente a cena" (FERREIRA, 2008, p.12-13). No caso do jovem rico o raciocínio é o mesmo: Quando o autor encobre a identidade do jovem, no segundo plano, abre uma lacuna que permite que a figura do jovem e a mensagem implícita na narrativa sejam aplicadas a todo ser humano. Antes de uma falha no texto este recurso se trata de uma ferramenta que o universaliza e inviabiliza a interpretação sintomática do mesmo.

$\mathrm{Na}$ linha de interpretação teológica dizemos que a opção por essa narrativa advém da semelhança de desejos do jovem em questão com os jovens atuais. Parafraseando o biblista Ivo Storniolo no livro "Como ler o evangelho de Mateus: o caminho da justiça" (2011) pode-se dizer que, como o jovem do texto, "todo" (STORNIOLO, 2011, p.139) jovem anseia por experimentar a vida. O jovem rico deseja isso: a vida em plenitude, que é a vida de 
Deus em nós. Continuando, o biblista elabora uma pergunta retórica: Que deve fazer o jovem? E respondendo-a diz que Jesus o lembra de que deve observar os mandamentos e dá especial atenção àqueles que tratam da relação com o próximo, porque a vida de Deus em nós depende de tal relação. O jovem já os cumpria e queria mais. Então vem o desafio; "vender tudo o que possui, dar o dinheiro aos pobres, e depois colocar-se no seguimento de Jesus, isto é, na busca da justiça" (STORNIOLO, 2011, p.139). O jovem "resiste ao desafio: vai embora triste, porque era muito rico" (STORNIOLO, 2011, p.139).

A intencionalidade dos textos é menos dizer que o rico não vai para o céu do que dizer que a condição para o seguimento à Jesus e, consequentemente, o alcance da vida eterna é ter em Jesus o único tesouro, posto ser este o exemplo pleno de desprendimento no afã de doar-se plenamente ao serviço ao outro. Vale a pena recorrer a uma obra do escritor português Gil Vicente, cujo título "Auto da barca do inferno" faz ver, de forma alegórica, que o não desprendimento condiciona o homem a viver amarrado aos bens materiais, terrenos, mesmo após a morte. Na referida foi um homem paupérrimo, o sapateiro, que não conseguiu desprender-se. Estando prestes a fazer a travessia trazia consigo sua caixa de engraxar sapatos. Conclusão: não foi capaz de atender ao "segue-me" de Jesus, mesmo sendo pobre da mesma maneira que não o atendeu o Jovem rico.

Storniolo em outro momento do já citado livro afirma que o evangelho de Mateus foi o mais importante para as comunidades primitivas e o texto que as ajudou a escrever suas histórias. "Até o fim do século II foi o evangelho mais importante, e praticamente formou o alicerce das comunidades cristãs" (STORNIOLO, 2011, 
p.8). Também é o mais adequado para fazer a passagem do Antigo para o Novo Testamento, uma vez que Mateus, um judeu convertido, escreve para comunidades de origem análoga à dele. Assim o texto de Mateus "era o mais apropriado para anunciar a passagem das promessas contidas no Antigo Testamento para a sua realização em Jesus e por meio dele. " (STORNIOLO, 2011, p.8).

Aos articulistas o fato de o texto de Mateus ter sido tão significativo para as primeiras comunidades oferece as razões para desenvolver o artigo a partir de sua narrativa. Dentre as preocupações de Mateus estava o fechamento das comunidades cristãs. Ele deseja mostrar que a mensagem cristã é libertação e abertura ao outro. Como diz Storniolo. Ele "quer mostrar que as comunidades não devem ficar fechadas em si mesmas, um olhando para o outro, mas se abrir para todos, levando a todos os tempos e lugares a palavra e a ação que libertam para vida nova. " (STORNIOLO, 2011, p.9).

Mateus escreve motivado pelo compromisso com o "segue-me" de Jesus. Ele, que o fazia na íntegra, alertava a comunidade para desprender-se em favor do outro. Para os articulistas esse objetivo continua na ordem do dia. Nosso contexto é formado por pessoas cada vez mais fechadas em si e indiferentes ao outro, como o Jovem rico do evangelho, mas não só, também o sapateiro do Gil Vicente. Uma sociedade feita do provisório e descartável. Zygmunt Bauman a identifica como fluida. Líquidos sob qualquer pressão se alteram. Sua forma é provisória e depois de utilizado é rapidamente descartado. "Os fluidos se movem rapidamente. Eles 'fluem', 'escorrem', 'esvaem-se', 'respingam', 'transbordam', 'vazam', 'inundam', 'borrifam', 'pingam'; são 'filtrados', 'destilados'; diferentemente dos sólidos, não são facilmente contidos" (BAUMAN, 
2011, p.8). Desta forma "essas são razões para considerar "fluidez" ou "liquidez" como metáforas adequadas quando queremos captar a natureza da presente fase". (BAUMAN, 2011, p.9)

Storniolo nos lembra de que ao lermos os evangelhos devemos ater-nos "a como o evangelista apresenta Jesus" (2001, p.12). Mateus apresenta, em especial, a face de Jesus libertador dos pobres, assim como o Cristo promotor da Justiça. Esta justiça é fruto do empenho para se construir o Reino de Deus. O que só é possível quando nos desprendemos de nós mesmos. "O Jesus de Mateus é, portanto, o Mestre da Justiça. " (STORNIOLO, 2001, p.15). Essa postura do mestre deve guiar a comunidade que deve propagar esta mensagem "isso não deve ficar dentro da comunidade apenas. Deve ser ensinado a todos, para que todos aprendam de Jesus qual é a justiça que Deus quer." (STORNIOLO, 2011, p.15) Não é possível construirmos a justiça se antes não deixarmos Deus nos tocar e irmos ao encontro do outro. Cada um deve dar a sua resposta, que, embora seja pessoal, possui impacto coletivo. Em uma pergunta de cunho retórico questionamos quais, em nosso contexto, têm sido nossa resposta diante dos desafios a nós impostos pela fase fluida da modernidade? Da resposta depende, em parte, a recompensa.

Storniolo questiona, considerando os discípulos que "deixaram tudo para seguir Jesus. O que vão ganhar?". Ele se responde que, no agora, "apenas a alegria de se entregar a causa da justiça", porém "quando o Reino chegar (...) o sentido da vida será pleno, pois a experiência da fraternidade e da partilha fará descobrir o que é, afinal, a própria vida de Deus.". (STORNIOLO, 2011, p.40).

Por fim, temos de ter claro que o literário e o teológico caminham juntos no texto bíblico e que estes aspectos são faces de 
algo divino que mantem relação com o nosso humano. Nas palavras de Ferreira, reconhecer que a Bíblia e em especial as narrativas bíblicas são literárias "implica o reconhecimento que elas guardam certa relação de proximidade/distância com a realidade, nunca sendo mera transcrição desta, pelo contrário, representando-a e buscando transformá-la por intermédio das histórias narradas" (FERREIRA, 2008, p.10).

Os formalistas russos afirmam que literatura é "a escrita que, nas palavras do crítico russo Roman Jakobson, representa uma 'violência organizada contra a fala comum" (EAGLETON, 2006, p.3). Em outras palavras: "literatura é uma forma 'especial' de linguagem, em contraste com a linguagem 'comum' que usamos habitualmente." (EAGLETON, 2006, p.7). Apropriando-se deste conceito de literatura Ferreira afirma que é de grande importância o trabalho linguístico realizado no texto por meio da metáfora. "Esta, antes de ser uma mera figura de linguagem, é uma linguagem, aprofundando e gerando indefinições de entendimento que invocam a colaboração do leitor no processo interpretativo." (FERREIRA, 2008, p. 10).

Aqui manifesta-se a dialética autor/leitor que constrói o sentido total do texto. $O$ texto sagrado não foge a isto: $O$ verdadeiro autor do texto sagrado é Deus (aspecto teológico) que se utiliza de autores hagiográficos para redigir o texto (aspecto literário) o texto fruto desta inspiração comunica e ganha novos sentidos quando é contrastado com a vida de cada leitor. Esta relação (Deus - autor hagiográfico) será melhor explorada mais à frente. Basta nos atermos, neste momento, que por meio do texto sagrado o leitor/ interlocutor se coloca em diálogo com o Inspirador deste texto: o próprio Deus. Nesta relação o texto ganha novos sentidos frente à 
realidade do leitor.

Em suma: "o texto literário se constrói como um 'jogo entre escritor e leitor'." (FERREIRA, 2008, p.10) sendo, este, uma chave para a interpretação da realidade histórica vivenciada pelo próprio leitor. Diante do exposto afirma-se que é nesta relação Deus homem por meio do texto sagrado que a bíblia deixa de ser um conjunto de palavras para ser a Palavra de Deus. Isto explica a expressão cristã que afirma que não somos a religião da letra, mas da Palavra.

\section{Palavra de Deus: Uma proposta}

Comunidades alimentadas pela Palavra de Deus se fortalecem nas raízes da experiência cristã. Tal afirmação fica mais evidente, a partir dos documentos aprovados pelo Concílio Ecumênico Vaticano II promovido pela Igreja Católica Apostólica Romana entre os anos de 1962 a 1965.Um deles, a constituição dogmática Dei Verbum, que trata da relação dos cristãos com a Palavra de Deus, afirma que o que está contido e manifestado, por Deus, "na Sagrada Escritura, foram escritas por inspiração do Espírito Santo". (Papa Paulo VI "Dei Verbum") Tal inspiração deu-se da seguinte maneira: O Espírito Santo utilizou-se, holisticamente, dos autores hagiográficos "para escrever os livros sagrados". (Paulo VI "Dei Verbum")

Esse procedimento outorga a autoria da Sagrada Escritura ao próprio Deus e, mais que isso, faz de Deus o ser que confere e concede veracidade à mesma. Desta forma a lgreja segundo a sua fé tem por "santos e canônicos [...] os livros inteiros do Antigo e do Novo Testamento [...] porque escritos por inspiração do Espírito Santo [...] têm Deus por autor, e como tais foram confiados 
à própria Igreja." (Papa Paulo VI "Dei Verbum") Essa realidade só pode ser considerada a luz da fé. Neste sentido Jesus proclamou "felizes os que acreditaram sem terem visto" (Jo 20, 29) Isto é, felizes os que têm fé.

Diante disto, atemo-nos, ao reconhecimento da ação da Trindade, pela fé, pois essa é um "dom gratuito de Deus e acessível a quantos a pedem humildemente" (Catecismo da Igreja católica compêndio) A "fidei" "é operante "por meio da caridade» (Gal 5,6 )" além de estar "em contínuo crescimento, graças, em especial, à escuta da Palavra de Deus e à oração." (Compêndio do Catecismo da Igreja católica) A porta da fé nos leva a Deus. Sobre isso o Papa Bento XVI, em sua Carta Apostólica Porta Fidei nos diz que "A porta da fé (cf. Act 14, 27) [...] está sempre aberta para nós." Atravessamo-la "quando a Palavra de Deus é anunciada e o coração se deixa plasmar pela graça que transforma." No entanto atravessá-la "implica embrenhar-se num caminho que dura a vida inteira." (Bento XVI "Carta apostólica").

$\mathrm{Na}$ constituição Pastoral Gaudium et Spes, promulgada pelo Papa Paulo VI, a Igreja define-se companheira dos homens pois "as alegrias e as esperanças, as tristezas e as angústias dos homens de hoje, sobretudo dos pobres e de todos aqueles que sofrem, são também as alegrias e as esperanças, as tristezas e as angústias dos discípulos de Cristo" (Paulo VI "Constituição pastoral") e, sendo assim, a Igreja volta-se para o homem e sua realidade na certeza de que "não há realidade alguma verdadeiramente humana que não encontre eco no seu coração." (Paulo VI "Constituição pastoral"). Por consequência disto, ela reafirma que é alicerçada em Cristo, mas construída por homens. (Paulo VI "Constituição pastoral'). Desse fato, entende os articulistas, que a experiência 
vivida pelos primeiros cristãos possa ser experimentada na atualidade, considerando-se que a palavra inspirada continua a mesma: Palavra inspirada que revela o desejo de Deus aos homens. Isto é, os primeiros tinham acesso, em princípio, à Palavra por meio da oralidade. Hoje, tem-se o texto escrito. Assim o que importa é a comunicação mantida com a Palavra, que é o próprio Cristo, e o transbordar disto na realidade de cada cristão. O meio pelo qual a comunicação se mantém é ferramenta nas mãos de Deus para se alcançar este objetivo.

Quanto à interpretação dos textos sagrados, estudiosos da linguagem já nos alertaram para os sentidos de um texto, a partir do seu contexto, como também o fez o Papa Bento XVI, no documento Verbum Domini. Este, de um lado "sublinha, como elementos fundamentais para identificar o significado pretendido pelo hagiógrafo, o estudo dos gêneros literários e a contextualização; por outro, devendo a Escritura ser interpretada no mesmo Espírito em que foi escrita". (Bento XVI "Verbum Domini"). Prossegue afirmando que a constituição Dogmática Dei Verbum oferece os critérios para uma correta interpretação. São eles: $1^{\circ}$ "interpretar o texto tendo presente a unidade de toda a Escritura" $2^{\circ}$ "ter presente a Tradição viva de toda a Igreja" $3^{\circ}$ "observar a analogia da fé." Por fim "«Somente quando se observam os dois níveis metodológicos, histórico-crítico e teológico, é que se pode falar de uma exegese teológica, de uma exegese adequada a este Livro»". (Bento XVI "Verbum Domini")

Jesus reinterpretou muitos aspectos da Lei judaica. Ele instruía de uma maneira totalmente nova. Não se detinha sobre a Lei, sobre a letra, mas ensinava de acordo com a vontade que nascia do coração de Deus. Concretizando esta postura ele estava ao lado 
dos mais necessitados. (Mc 1, 40-45).

Outra argumentação que confirma a possibilidade da verdadeira experiência cristã hoje pode ser desenvolvida a partir do documento Verbum Domini do Papa Bento XVI. Aí ele disserta sobre da Sacramentalidade da Palavra. A Palavra é sinal vivo de Deus na nossa vida. Este fato pode ser entendido "através da analogia com a presença real de Cristo sob as espécies do pão e do vinho consagrados." Quando vamos a Missa, comungamos o corpo e o sangue de Jesus. Da mesma forma ao se proclamar a Palavra "é o próprio Cristo que Se faz presente e Se dirige a nós para ser acoIhido." (Bento XVI "Verbum Domini")Por fim a Dei Verbum atesta que "Realmente presente nas espécies do pão e do vinho, Cristo está presente, de modo análogo, também na Palavra proclamada na liturgia." (Bento XVI "Verbum Domini").

A comunidade reunida, em torno da palavra, entra em comunhão com ela e, por meio dela, com o próprio Cristo presente na Palavra. Esta é a força eucarística da Palavra Sagrada. A Palavra de Deus, sendo gerada por Deus, orienta ao homem como ele deve viver e, sendo a Palavra, pelo Espírito Santo, capaz de ser aplicada a todo contexto e forma de vida humana, torna-se um dos meios que possibilitam, no hoje, a ocorrência da experiência cristã dos primeiros seguidores de Cristo.

\section{Individualismo:}

\section{Um desafio moderno a proposta da Palavra de Deus.}

Até este ponto os articulistas trabalharam para apresentar a Palavra de Deus como meio para a experiência do chamado ao seguimento feito por Jesus aos seus seguidores de todos os tempos. Com isso pretendíamos identificar o que é convergente 
na experiência do "segue-me" feita pelos primeiros cristãos e os discípulos de Jesus em tempos de modernidade líquida. É preciso que reconheçamos, assim como o fez o grande poeta Carlos Drummond de Andrade: "Há uma pedra no meio do caminho". A pedra da individualização levou o homem a recusa daquilo que é comum, que é comunitário ou a "flexibilização" do comunitário. Denuncia Bauman: "A individualização chegou para ficar; toda elaboração sobre os meios de enfrentar seu impacto sobre o modo como levamos nossas vidas deve partir do reconhecimento desse fato." (BAUMAN, 2011, p.47). A experiência cristã, no hoje, não é impossível, mas deve levar em consideração o que é próprio do nosso contexto. O processo de individualização vem sendo construído na sociedade desde o despertar da modernidade e em suas diferentes fases. Em cada fase foi-se afetando uma face da vida social. Por fim os sólidos, isto é, tudo aquilo que a vida e o relacionamento social tinham por elemento guia, elemento de certeza, ou seja, toda a gama de valores e tradições que guiavam a vida e o relacionamento das e entre as pessoas, se liquefizeram. Bauman utilizando perguntas retóricas questiona: "a modernidade não foi 'liquefação' desde o começo? Não foi o 'derretimento dos sólidos' seu maior passa tempo e principal realização? Em outras palavras, a modernidade não foi 'fluida' desde a sua concepção? (BAUMAN, 2011, p.9)

Este é o contexto em que, hoje, se manifesta o chamado de cristo a todo ser humano. A marca desta fase é a "individualização". Bauman afirma que "A apresentação dos membros como indivíduos é a marca registrada da sociedade moderna" (BAUMAN, 2011, p.39). Esse processo tornou o ser humano totalmente voltado para si, para seus desejos, vontades e necessidades. Escreve 
Bauman compilando o pensamento desta fase. "Não olhe para trás, ou para cima; olhe para dentro de si mesmo, onde supostamente residem todas as ferramentas necessárias ao aperfeiçoamento da vida - sua astúcia, vontade e poder." (BAUMAN, 2011, p.38).

É uma sociedade que exalta o egoísmo. Uma sociedade que desde os seus primeiros tempos quis e promoveu a "libertação" do homem em relação ao comunitário. Isso tirou do ser humano a identificação com um grupo, fator que influenciava, muito mais do que hoje, na definição da identidade da pessoa. O processo de individualização colocou nas mãos de cada indivíduo a obrigação de autoconstruir sua identidade. Bauman proclama, em poucas palavras, este fato com a seguinte afirmação: 'a 'individualização' consiste em transformar a 'identidade' humana de um 'dado' em uma 'tarefa' e encarregar os atores da responsabilidade de realizar essa tarefa e das consequências (assim como dos efeitos colaterais) de sua realização." (BAUMAN, 2011, p.40). A comunidade já não é mais referência para as pessoas. $O$ sentimento de pertença a uma comunidade foi letalmente atacado pela modernidade. Ao se falar da comunidade eclesial esse ataque gerou a despreocupação, a falta de engajamento e uma vivência da fé só em bases sentimentais. O elo fé - comunidade, como um sólido do cristianismo, não passou sem sofrer seus abalos, sua liquefação.

A atual sociedade prega que nós nos bastamos a nós mesmos. Isto nos leva a rechaçar o outro. "O que quer que os indivíduos façam quando se unem, e por mais benefícios que seu trabalho conjunto possa trazer, eles o perceberão como limitação à sua liberdade de buscar o que quer que lhes pareça adequado separadamente, e não ajudarão." (BAUMAN, 2011, p.45).

Os articulistas, atentos a fala de Bauman, concluem que o co- 
munitário, para o homem de hoje, é visto como prisão que impossibilita a plena manifestação da liberdade humana. Por outro lado, a recusa do comunitário condena o ser humano ao isolamento. $A$ solidão é o marca passo do coração humano de hoje. Isto gerou comunidades nas quais os laços humanos são frágeis e o compromisso com o comum é débil. "A única vantagem que a companhia de outros sofredores pode trazer é garantir a cada um deles que enfrentar os problemas solitariamente é o que todos fazem diariamente" (BAUMAN, 2011, p.45).

Em âmbito de experiência cristã o isolamento do indivíduo cria uma capa impermeabilizante para a mesma experiência. Não estamos defendendo que fujamos de nosso contexto histórico, social, familiar. Defendemos e atestamos que a individualização, por mais que à primeira vista pareça, não impede, de um todo, que a experiência seja feita. Ela, sim, dificulta. Um caminho para a experiência está na cidadania. Bauman contrapõe o cidadão e o indivíduo. "O 'cidadão' é uma pessoa que tende a buscar seu próprio bem-estar através do bem-estar da cidade - enquanto o indivíduo tende a ser morno, cético ou prudente em relação à 'causa comum', ao 'bem-comum', à 'boa sociedade', ou à 'sociedade justa'." (BAUMAN, 2011, p.45). O cidadão assim como o cristão aceita o bem-estar, quer tê-lo, mas ele não pode possuí-lo sabendo que existe muitos outros homens definhando de fome, sede etc.... Assim o bem-estar que é usufruído pelo cristão deve vir por meio do comum.

\section{Catequese contemporânea: urgência de uma nova práxis}

Nessa fase do presente artigo discutiremos como a fase líquida da modernidade atinge a catequese local onde, teoricamente, o cristão deveria ter um contato mais íntimo com a Palavra e assim 
ser despertado para a sua missão no mundo. Este contato que se torna o "start", como já destacamos, para a verdadeira experiência cristã. Experiência que conduz a uma resposta positiva ao chamamento de Cristo.

Muitos catequetas e teólogos se colocam a produzir uma intensa gama de material científico sobre o tema. Neste nosso trabalho seguiremos a trilha da Dra. Solange Maria do Carmo. Em sua tese de doutorado a presente pesquisadora se coloca a refletir sobre a grande crise da catequese na atual fase histórica.

A autora inicia sua fala refletindo sobre a origem da crise catequética. Ela identifica a citada crise dentro de uma crise maior: a crise do cristianismo. Esta é real e corrói a instituição eclesial. Dissertar sobre a crise da catequese significa admitir que ela é filha de uma crise muito mais profunda. Assim a crise cristã "se estende também para o campo catequético." (CARMO, 2012, p. 25)

A pesquisadora reconhece que nem tudo está perdido, que na escuridão da crise há luzes tímidas de esperança, sinais da graça de Deus agindo, no entanto, estas luzes "não conseguem ofuscar a dolorosa realidade de um sistema em crise" (CARMO, 2012, p.25). Diante desta realidade a autora reconhece que é preciso dedicação para se levar adiante o evangelho. Diz ela que esta realidade "nos impulsiona a buscar sempre o melhor de nós, como colaboradores na obra divina da evangelização." (CARMO, 2012, p.25). Os articulistas partilham desta empolgação da Doutora. Reconhecese o desafio, mas o desejo de ajudar na divina obra de evangelizar faz da crise um estímulo a melhorar.

A autora desdobra o tema em sinais, fortemente presentes na sociedade, desta crise catequética, a saber, "a crise da transmis- 
são [...]; o fracasso do processo tradicional de iniciação [...]; e a precariedade da catequese com adultos" (CARMO, 2012, p.23).

Ao dizer crise de transmissão a autora se refere ao número sempre crescente de pessoas das novas gerações que não são adeptas ao cristianismo, ou seja, as novas gerações estão se distanciando do cristianismo. "Apesar de os catequetas entenderem que a crise de transmissão tem contornos para além de suas fronteiras e acontece também em outros setores da sociedade, não deixa de ser preocupante o fato de ela não poupar a catequese." (CARMO, 2012, p.26). Após uma análise estatística do cristianismo na França, a qual não iremos pormenorizar, pois não é este o nosso foco, basta que saibamos que esta análise deixa evidente a queda vertiginosa de cristãos entre as novas gerações, a autora conclui "que a crise da catequese não é, em primeiro lugar, uma crise dos meios de transmissão, uma vez que o século XX foi muito frutuoso nos descobrimentos psicopedagógicos." (CARMO, 2012, p.27). Para a autora "a crise se assenta sobre um questionamento acerca do que é transmitido. Parece que o que está sendo transmitido perdeu sua importância para o mundo contemporâneo." (CARMO, 2012, p.27). Para os articulistas esta fala da autora deixa transparecer que a crise da catequese, e por consequência a crise do cristianismo, se trata, na verdade, de uma crise de fé.

A nossa catequeta prossegue analisando o "fracasso do processo tradicional de iniciação cristã" (CARMO, 2012, p.27).

Desde o Papa Pio X a Igreja investe na catequese como preparação para a primeira eucaristia de crianças. "Pensava-se que, uma vez recebida a fé no seio da família que garantia o batismo a seus filhos, a catequese deveria completar o processo de iniciação cristã, dando-Ihe acabamento." (CARMO, 2012, p.27) Como 
resultado deste processo tem-se hoje pais que não são evangelizados, incapazes de transmitir a seus filhos a fé. "E se a fé não flui mais naturalmente na família, a catequese não pode mais se dar ao luxo de acompanhar ou burilar uma fé que não existe, visando ao acabamento do processo iniciático." (CARMO, 2012, p.27). A catequese hoje tem a árdua missão de primeiro despertar o desejo pela profissão de fé, ajudar aqueles que desejam fazer o caminho e concluir ajudando ao neo-cristão a viver a fé em sua plenitude. (CARMO, 2012).

Hoje, no entanto, há um perigoso descompasso entre a necessidade da Igreja e o que a catequese está oferecendo a mesma. "O sistema catequético foi elaborado para 'nutrir a fé' e não para 'propor a fé'” (CARMO, 2012, p.28). Diante desta realidade a autora questiona: "Como fazer um paciente e elaborado trabaIho evangelizador para que os catequizandos se interessem pelo evangelho e respondam pessoalmente ao apelo do Deus de Jesus Cristo que Ihes fala?" (CARMO, 2012, p.28). A autora admite que para se dar uma resposta a altura da pergunta será preciso um gigantesco trabalho que terá de mudar uma mentalidade de séculos de tradição. "São séculos de um trabalho catequético realizado em ritmo que não agrada nem funciona mais, e mexer nessa música certamente vai exigir muito traquejo para não se perder o passo da dança" (CARMO, 2012, p.28).

Entre os desafios a esta mudança está o conceito tradicional de iniciação. O processo de iniciação foi pensado para pessoas sem o batismo, porém, hoje, se tem batizados não evangelizados. Assim "nos dizeres de Derroite: 'o processo de iniciação cristã tornou-se processo de conclusão para muitos porque ele fecha o período de prática religiosa de muitos jovens"' (CARMO, 2012, 
p.29). A causa disto pode estar no descompasso entre o que é oferecido pela Igreja e o que o povo almeja, isto é, a Igreja oferece uma proposta de vida por meio dos sacramentos, enquanto o povo tem nos sacramentos manifestações folclóricas. (CARMO, 2012). Caminhos de vida são sólidos e muitas vezes limitam a liberdade de se fazer o que se quer. Como já foi dito nós somos constantemente estimulados a abandonar os sólidos. (BAUMAN, 2001).

Em relação à catequese com adultos a realidade não é muito melhor. Carmo constata em sua pesquisa que uma "verdade é desconcertante: a catequese não sabe catequizar adultos; ela foi totalmente pensada para a infância" (CARMO, 2012, p.30). Junto a este triste fato tem-se "a caducidade da linguagem religiosa" (CARMO, 2012, p.30). Isto é, a comunidade e em consequência a catequese, usa uma linguagem que nada fala ao homem de hoje. (CARMO, 2012). Esta realidade é um dos pilares da crise. Se não há uma comunicação entre comunidade, catecúmeno, realidade vivenciada é impossível uma fé sólida que permita a transformação da realidade e, portanto, não se tem uma autêntica experiência do cristianismo, haja vista que é inerente a esta transformação a melhora do mundo que se tem de entorno ao cristão.

No terceiro capítulo de sua tese a pesquisadora se coloca a refletir sobre os desafios catequéticos vivenciados especificamente na pós-modernidade, ou, como é denominada esta fase por Bauman, Modernidade líquida.

A proposta da autora para este capítulo de sua tese é "pontuar as mais significativas mudanças da gramática simbólica do homem contemporâneo levantadas pelo teólogo francês Denis Villepelet e, depois, considerar seus influxos sobre a catequese." (CARMO, 2012, p.127). A autora pergunta: como transmitir a fé ao 
homem de hoje?

Para responder a esta pergunta ela inicia uma análise do hoje, isto é, da pós-modernidade. Para ela se trata de um tempo "multirreferencial" (CARMO, 2012, p.127). Em outras palavras "uma sociedade de ethos não evolucionário se impõe hoje." (CARMO, 2012, p.127). Ela explica esta afirmação da seguinte forma: "O futuro não se apresenta mais como um hoje aumentado e melhor. Ele pode ser qualquer coisa, inclusive a irrupção do inesperado, a não continuidade do que se construiu. Tudo depende das oportunidades que se descortinam no horizonte do acaso." Nas palavras de Bauman (2001) tudo é fluído.

Mudou-se também a maneira pela qual se trabalha com o espaço e o tempo: "Coma virtualização dos espaços, promovida pelo mundo da internet e pela facilidade de movimentação no planeta, o homem contemporâneo está em toda parte e em lugar nenhum." (CARMO, 2012, p.127). Ao que toca o tempo ele volta seus olhos para o presente "O passado já se foi e não volta mais. Ele não recebe mais a tradição como outrora. O futuro ainda não chegou e tornou-se nebuloso. Resta-lhe apenas o presente, o instante atual, do qual ele deve fruir todo prazer, antes que a morte o visite." (CARMO, 2012, p.128). A sociedade de hoje também vive a ditadura do digital. A substituição do simbólico pelo digital. "Tudo se comunica e se intercomunica na tela de um computador, de uma televisão, de pequenos aparelhos eletrônicos que se tornaram companheiros diários." (CARMO, 2012, p.128). Desta forma "o mundo virtual ganha credibilidade e sua força irrompe de tal forma que o real fica referido a ele." (CARMO, 2012, p.128).

E qual a relação disto tudo com a práxis catequética? Vejamos o que nos diz a autora. 
São apresentados quatro desafios para a catequese frente ao contexto atual. O primeiro é "O desafio da interioridade, a obrigação de construir sua própria identidade, impõe-se devido à fragmentação da sociedade e à falta de referências a que o homem contemporâneo está sujeito." (CARMO, 2012, p.129); Segundo: "O desafio querigmático advém da secularização e do apagamento da memória cristã na sociedade, do déficit de iniciação cristã que hoje é observado em nosso meio." (CARMO, 2012, p.129); terceiro "O desafio educativo surge da incompatibilidade da transmissão da experiência cristã com a pedagogia escolar do ensino-aprendizagem." (CARMO, 2012, p.129); quarto: "O desafio comunitário se delineia no cenário atual como um dos mais difíceis a ser superado. Ele vem da subjetivação da fé, própria da psicologização do social. [...]. E a fé cristã, essencialmente eclesial, ficou com seus laços de pertença afrouxados. ". (CARMO, 2012, p.129).

Em conclusão a este capítulo e relacionando os conceitos supracitados Carmo atesta que se percebe "que a fé cristã se encontra hojedesafiada a dar uma resposta a esse mundo. " (CARMO, 2012, p.176). Isto porque "o fato de nossa sociedade se encontrar em estado permanente de crise não significa que ela é avessa ao evangelho." (CARMO, 2012, p.176). No entanto "a fé não pode mais ser vista como uma herança, um legado transmitido uma vez por todas, mas como um processo constante de crise, que se desencadeia graças ao escândalo do mistério pascal." (CARMO, 2012, p.176). A práxis catequética tem de se alterar para atender as necessidades do homem pós-moderno.

Relacionando os desafios pós-modernos da catequese e a práxis catequética no hoje destaca a autora que "o desafio da interioridade nos impele a ajudar os catequizandos na procura de 
si mesmos, sem confundir personalização com busca narcísica de si." (CARMO, 2012, p.176). Em relação ao segundo desafio o "desafio querigmático, Villepelet mostrou como se faz urgente dar maior acento ao polo querigmático da fé sem, no entanto, perder as conquistas que o polo antropológico alcançou." (CARMO, 2012, p.177). Quanto ao desafio educativo a autora, a partir de Villepelet, mostra que a pedagogia escolar moderna "elimina o mistério, pois o entende como um enigma a ser decifrado ao fim das especulações humanas. Se, na fé cristã, o mistério pascal tem primazia, essa pedagogia não seapresenta como a mais oportuna para a comunicação da fé." (CARMO, 2012, p.177). Desta forma "O desafio pedagógico da catequese consiste em descobrir ou redescobrir a pedagogia original da fé: a iniciação." (CARMO, 2012, p.177).

Prosseguindo "Quanto ao desafio comunitário, talvez o mais difícil de ser encarado, Villepelet insiste que a subjetivação da crença e o individualismo não eliminam a partilha e a troca de experiências". Assim "o Deus de Jesus Cristo se comunica no íntimo do coração, mas não no isolamento, porque em Cristo todos se tornam irmãos" (CARMO, 2012, p.177). A fraternidade é um imperativo para a experiência cristã de Deus.

Os articulistas concluem, afirmando de forma uníssona à nossa autora que "urge pensar a catequese sobre novas bases" (CARMO, 2012, p. 179). É preciso ressaltar que os articulistas não fazem um juízo de valor em relação à catequese. Fazemos sim uma breve análise de seu desenvolvimento e de suas condições no hoje, assim como suas urgências para o amanhã. Diante de tudo o que foi pensado e supra exposto permanece a questão: "Neste contexto de diáspora, onde os cristãos são em pequeno número e estão dispersos no meio do mundo, qual o papel da ca- 
tequese?" (CARMO, 2012, p.190).

Esta é uma complexa questão. Descrevendo o pensamento de Villepelet nossa autora explicita a já evidente necessidade de trocar uma catequese de cunho antropológico por uma catequese querigmática. Uma catequese que se preocupa em fortalecer uma fé já presente por uma catequese que propõe a fé. "Deus desapareceu do horizonte cultural e sua presença não é mais evidente" (CARMO, 2012, 190). Diante deste fato, "Diante de tantas angústias, tantos medos e inseguranças, o homem pós-moderno se pergunta como Castro Alves: Deus! ó Deus! onde estás que não respondes?" (CARMO, 2012, p.190-191).

Essa postura de Deus "Para Villepelet, esse escondimento de Deus, próprio das sociedades secularizadas, interpela a Igreja a dar uma orientação resolutamente mais querigmática que antropológica à catequese." (CARMO, 2012, p.191). Isto não é de todo ruim, pode ser, na realidade, uma oportunidade. "A ausência de Deus é uma ocasião para sua descoberta; a secularização é oportunidade de verdadeira experiência religiosa." (CARMO, 2012, p.191)

De uma análise mais acurada da sociedade já se percebe que "o cristianismo perdeu seu caráter instituído, mas não perdeu sua força instituinte, transformadora." (CARMO, 2012, p.191). Isto, porém "convida a uma conversão: a passagem de uma catequese que mantém e consolida a fé a uma catequese que propõe a radical novidade do evangelho." (CARMO, 2012, p.191) Isto se faz urgente já que "para o homem pós-moderno, a proposta cristã não passa de lengalengas sem sentido, de velhas histórias desgastadas, que nada mais têm a oferecer" (CARMO, 2012, p.192). Conclui a autora: "Insistir no polo querigmático da catequese é tor- 
nar a boa-nova conhecida, revelando todo seu frescor e toda sua singularidade."(CARMO, 2012, p.192).

\section{Comunidade: Igreja viva a catequisar}

Juan A. Ruiz de Gopegui, SJ em artigo intitulado "Catequese e comunidade cristã" deixa bem claro que para se renovar a catequese é necessária uma renovação da comunidade cristã. Por renovação os articulistas intendem o retorno à mensagem, ou meIhor, a pessoa que funda o próprio cristianismo: Jesus de Nazaré.

Mais do que imitadores de Cristo somos discípulos, isto é, amigos que com ele se coloca à mesa para escutá-lo e seguir suas orientações. Gopegui lembra que "o Rito da Iniciação Cristã dos Adultos, que restaura o catecumenato em várias etapas, mostra bem como toda a comunidade cristã é responsável pela catequese." (2005, p.325). Ele prossegue explicando que na segunda e terceira fase do processo de iniciação o catecûmeno é convidado a partilhar com os demais membros da comunidade a celebração litúrgica da Palavra. Ele não descarta a necessidade de uma catequese especializada àquela pessoa, no entanto, o que é absorvido pelo catecûmeno "convergirá para o momento da celebração litúrgica da Palavra, no qual tem lugar a 'iniciação' à escuta e acolhida de uma Palavra pronunciada pelo próprio Deus no coração do catecúmeno, em comunhão incipiente com a comunidade." (GOPEGUI, 2005, p.325). Desta forma "fazer, no seio da comunidade, a experiência espiritual de reconhecer e acolher uma Palavra, cuja origem, para além dos lábios humanos que a proclamam, remonta ao Deus vivo, é o cerne irrenunciável da iniciação cristã." (GOPEGUI, 2005, p.325) Por isso "fica patente que o su- 
jeito principal da catequese é a comunidade cristã, por ser sujeito da celebração litúrgica como afirma a Constuição Sacrosanctum Concilium sobre a Liturgia." (GOPEGUI, 2005, p.326)

Assim a liturgia deve dar fruto na vida do cristão. Para isto acontecer, no entanto, "depende em grande parte o resultado da catequese como iniciação permanente à vida cristã. $E$ isto obriga a afirmar que depende da qualidade da vida toda da comunidade cristã - porque os sacramentos são sinais de realidades que acontecem na vida toda." (GOPEGUI, 2005, p.326)

É, portanto, uma urgência a maturação da fé. A fé amadurecida é aquela que "surge quando uma pessoa reconhece, na figura de Jesus Cristo, presencializada significativamente pelo testemunho eclesial do querigma, o próprio Deus dirigindo-se a ela e convidando-a a estabelecer com Ele uma relação de amor." (GOPEGUI, 2005, p.327).

Segundo o autor, em Deus está as respostas para todas as questões humanas. Vale salientar que os articulistas endoçam este posicionamento. Isto também nos diz "que a experiência de Deus, na atual condição humana é sempre mediada pela experiência dos outros e do mundo." (GOPEGUI, 2005, p.327). Exclarece o autor:"Eis porque a catequese para conduzir a uma experiência de Deus, capaz de amadurecer com o amadurecimento da vida, terá que ajudar a pessoa à compreensão progressiva da sua existência e do mundo que a circunda." (GOPEGUI, 2005, p.328)

Gopegui aprofundando sua fala afirma que "é dentro dessa visão de si e do mundo, que a figura de Jesus Cristo, apresentada pelo conjunto da vida da comunidade evangelizadora, deverá ser reconhecida como Palavra de Deus que pede uma resposta de 
entrega incondicional." (GOPEGUI, 2005, p.328)

Neste sentido não é um processo de repúdio do que a catequese já passou se trata sim "de recolher o longo e fecundo caminho de renovação, nos seus diversos aspetos - pedagógico, querigmático narrativo, profético, ecumênico - e integrá-los progressivamente com a totalidade da vida da comunidade cristã." (GOPEGUI, 2005, p.328). Desta forma "a catequese influenciará a vida da comunidade - a sua liturgia, a sua pastoral, os seus engajamentos sócio-políticos - e a vida da comunidade influenciará a catequese" (GOPEGUI, 2005, p.328).

\section{Conclusão}

A experiência cristã é possível hoje como foi antes. Estamos em um contexto que exalta o egoísmo, mas este não precisa ser o diapasão com o qual afinamos nossa vida. O cristão-cidadão deixa-se tocar pela Palavra num processo de interação com a mesma. Essa interação é possível porque o texto bíblico sendo inspirado pelo Espírito Santo e interpretado pela Igreja ganha sentido na vida da pessoa.

O literário e o teológico caminham juntos nesse processo. Uma vez que a pessoa passa a orientar a sua vida pela Palavra de Deus ela rompe com o individualismo e inicia a sua volta a um novo jeito de viver. A experiência do "segue-me" se concretiza. A realidade se transforma.

Neste processo a catequese tem uma especial contribuição a apresentar. Ela é o espaço da comunidade cristã onde as novas gerações são formadas. No entanto, este espaço hoje não atende as necessidades dos homens modernos. A pós-modernidade atin- 
giu em cheio o processo catequético. Isto fez dele um espaço que perdeu sua atratividade para as novas gerações.

É necessário reafirmar, porém que a catequese é espaço de atuação da graça divina. Muito já se atualizou na catequese. Aqui os articulistas se referem a atualizar como um processo aplicado ao meio de transmissão da mensagem catequética e não um processo que atinge a mensagem catequética. Há sim um longo caminha a se percorrer. Mas, enquanto Igreja, responderemos ao Senhor "Eis a escrava do Senhor. Faça-se em mim segundo a tua palavra" (Lc 1, 38).

\section{Referências bibliográficas}

BAUMAN, Zygmunt. Modernidade Líquida.1.ed. Rio de Jeneiro: Jorge Zahar Editor. 2001. 280p.

BAUMAN, Zygmunt. Comunidade.1.ed. Rio de Jeneiro: Jorge Zahar Editor. 2003. $144 p$.

CARMO, Solange Maria do. Catequese num mundo pós-cristão: estudo do terceiro paradigma catequético formulado por Denis Villepelet. 2013. 315f. Tese (Doutorado em teologia) - Faculdade Jesuíta de Filosofia e teologia/Departamento de teologia.

EAGLETON, Terry. Teoria da Literatura: uma introdução. 6. ed. São Paulo: Martins Fontes. 2006. 387p.

EVANGELHO SEGUNDO SÃO MATEUS. In: Bíblia Sagrada: edição pastoral. São Paulo: Paulus, 2005.

EVANGELHO SEGUNDO SÃO LUCAS. In: Bíblia Sagrada: edição pastoral. São Paulo: Paulus, 2005.

FERREIRA, João Cesário Leonel Ferreira. A Bíblia como Literatura - Lendo as narrativas bíblicas. Revista eletrônica Correlatio. n. 13, jun. 2008. Disponível em 〈https://www.metodista.br/revistas/revistasims/index. php/COR/article/viewFile/1650/1646.) Acesso em 10 abr. 2016. 
FILHO, Domício Proença. A linguagem literária. São Paulo: Ática, 1986. Série Princípios (p. 5-10 e 36-44)

GÊNESIS. In: Bíblia Sagrada: edição pastoral. São Paulo: Paulus, 2005.

GOPEGUI, Juan A. Ruiz de. Catequese e comunidade. Revista eletrônica Perspectiva teológica. v. 37. n. 103., 2005. Disponível em: «http://www. faje.edu.br/periodicos2/index.php/perspectiva/article/view/376/712 > Acesso em 18 abr. 2016.

IGREJA CATÓLICA. Papa (2005-2013 Bento XVI).Carta apostólica sob forma de motu proprio Porta fidei do sumo pontífice Bento XVI com a qual se proclama o ano da fé. Disponível em «http://w2.vatican.va/content/ benedict-xvi/pt/motu_proprio/documents/hf_ben-xvi_motu-proprio_20111011_porta-fidei.html> Acesso em 20 set. 2015.

IGREJA CATÓLICA. Papa (2005-2013: Bento XVI). Exortação pós-sinodal Verbum Domini do Santo Padre Bento XVI ao episcopado, ao clero, às pessoas consagradas e aos fiéis leigos sobre a Palavra de Deus na vida e na missão da Igreja. Disponível em 〈http://w2.vatican.va/content/benedictxvi/ pt/apost exhortations/documents/hf benxvi exh 20100930 verbum-domini.html> Acesso em 15 set. 2015.

IGREJA CATÓLICA. Papa (1978-2005: João Paulo II). Carta encíclica Ecclesia de eucharistia do sumo pontífice João Paulo II aos bispos,aos presbíteros e diáconos, às pessoas consagradas e a todos os fiéis leigos sobre a eucaristia na relação com a Igreja. Disponível emıhttp://www. vatican.va/holy_father/special_features/encyclicals/documents/hf_ jpii_enc_20030417_ecclesia_eucharistia_po.html> Acesso em 15 set. 2015.

IGREJA CATÓLICA. Papa (1963-1978: Paulo VI). Constituição conciliar sacrosanctum concilium sobre a sagrada liturgia. Disponível em: «http://www. vatican.va/archive/hist_councils/ii_vatican_council/documents/vatii_const_19631204_sacrosanctum-concilium_po.html> Acesso em 19 de mar. 2016.

IGREJA CATÓLICA. Papa (1963-1978: Paulo VI) Constituição dogmática. Dei verbum sobre a revelação divina. Disponível em: «http://www.vatican.va/archive/hist_councils/ii_vatican_council/documents/vatii_ const_19651118_dei-verbum_po.html.) Acesso em 19 de mar. 2016.

IGREJA CATÓLICA. Papa (1963-1978: Paulo VI) Constituição dogmática Lumem gentium sobre a Igreja. Disponível em: «http://www.vatican.va/archive/ hist_councils/ii_vatican_council/documents/vatii_const_19641121_ 
lumen-gentium_po.html> Acesso em 19 de mar. 2016.

IGREJA CATÓLICA. Papa (1963-1978: Paulo VI) Constituição pastoral Gaudium et spes sobre a igreja no mundo atual. Disponível em:ıhttp://www. vatican.va/archive/hist_councils/ii_vatican_council/documents/vatii_ const_19651207_gaudium-et-spes_po.html.) Acesso em 19 de mar. 2016.

IGREJA CATÓLICA. Compêndio do Catecismo da Igreja católica. Disponível em: (http://www.vatican.va/archive/compendium ccc/documents/ archive 2005 compendium-ccc po.html.) Acesso em 10 de dez. de 2015.

KOCH,I.V.; ELIAS,V.M. Escrita e interação. In: . Ler e escrever: estratégias de produção textual 2. ed. São Paulo: Contexto, 2015. Cap.2. p. 31-52. 